\title{
STUDENT LEADERSHIP IN SCHOOL: INTERNALIZATION OF ENTREPRENEURIAL COMPETENCE AND CHARACTER
}

\author{
Lelahester Rina \\ Satya Wacana Christian University, Diponegoro street 52-60, Salatiga, 50711, Indonesia \\ Email: lelahester.rina@staff.uksw.edu
}

\begin{abstract}
This paper aims to find the effort of internalizing competence and entrepreneurial character of students in Satya Wacana Christian Elementary School and Junior High School. The method used is a qualitative study through interview, observation and documentation, using data analysis from Spradley by analyzing of domain and its semantical relation. The results showed that the internalization of entrepreneurial competence and character had been applied through leadership activities so as to form the character and leadership skills of students. This study has implications for the school's efforts to give full attention for students to play a role in leadership activities and to provide support through a curriculum that supports the internalization of entrepreneurial competence and character.
\end{abstract}

Keywords: Entrepreneurial competence, entrepreneurial character, entrepreneurship education, student leadership, elementary levels.

\section{Introduction}

The introduction of entrepreneurship to students in education today is an important aspect of developing individual responsibility through financial, economic, social and entrepreneurial ethics. The process of experiencing in this learning is the mean to form the desired character of students according to learning objectives (Silanoi, 2012). The referred experience is the business of students' effort to involve in activities related to entrepreneurial activities.

Education is a platform for agents capable of changing the world. In other words, Rokhman, Syaifudin and Yuliati (2014) stated that education is not only for transferring knowledge but also as a container in shaping students' attitudes, behavior, character and leadership. Verzat and Bachelet (in Fayolle, 2006) mention that an important part to play in the education system is to promote entrepreneurial competence and spirit before entering entrepreneurship.

Some learning methods that can be used in the internalization of entrepreneurial competence and character are: learning though experience, action learning, learning from one's own mistakes, learning from other people, and earning by doing (Verzat and Bachelet in Fayolle, 2006; Kadir, Salim, \& Kamarudin, 2012). In parallel, networking and coaching activities are favored by many students (Küttim, Kallaste, Venesaar, \& Kiis, 2014). So, the outline of the process of internalization of entrepreneurial competence and character are more focused on experience-based learning and action.

Guidelines for the development of entrepreneurship education are specially made by the Ministry of National Education of Republic of Indonesia (Kementerian Pendidikan Nasional, 2010) entrepreneurship education is the joint responsibility of families, community and government and lasts a lifetime. In the process, this school always provides educational services, trainings for nature of science, attitude, and competence for students as well as entrepreneurial character. The government also directs educational institutions so that students are directed to entrepreneurial activities in order to foster the competence and entrepreneurial spirit. It can be interpreted that the internalization of the Entrepreneurial competence and character are not only given to the middle school level to prepare them to enter the world of work, but rather starting from the lowest and sustainable level on the next level (Ahmad, 2013). Heydari, Madani, and Rostami (2013) proved that some of the characters that can be formed include: motivation for success, innovation, self-belief, self-actualization.

Entrepreneurial competence and character can be developed through the process of educational activities because entrepreneurship education is a lifelong learning process. Gutierrez and Baquero (2017) mentions that the internalization of competence and entrepreneurial spirit is given from elementary school and continued at the next school level which seems to be apart from the process. In addition to emphasizing the value of characters that can be given to them, schools would need to prepare the curriculum with deepening knowledge in various subject areas of entrepreneurship (Welsh, Tullar, \& Nemati, 2016). The formation of this entrepreneurial character will have an impact on the success of an entrepreneur in terms of the quality of one's work (Ghina, 2014); as 
well as develop students' competences to assess, manage and use their emotions in challenging conditions of entrepreneurial entrepreneurship (Mortan, Ripoll, Carvalho, \& Bernal, 2014).

Internalization of entrepreneurial competence and character can be done through the development of student leadership in various activities. Rubens, Schoenfeld, Schaffer, and Leah (2018) explained today that teaching methods have changed toward the integration of active learning innovations associated with leadership practice. Rubens et al. (2018) stated that some of the methods used include: case studies, service-based learning, simulations, client-based consulting projects and student entrepreneurial endeavors. Some factors that influence student leadership competence include: 1) self-efficacy, self-confidence, emotional ability, 2) experience, peer communities, student organizing activities and leadership positions in the classroom, 3) school environment (Mozhgan, Parivash, Nadergholi, \& Jowkar, 2011).

Leadership can be gained from the direct experience of students on the real state of the school environment. Mozhgan et al. (2011) mentions that students can learn leadership skills through their involvement in the classroom as well as outside the classroom. This is also stated by Amirianzadeh, Jaafari, Ghourchian, and Jowkar (2011) factors that influence student involvement in organization such as student character, environment, back-ground, and condition before entering education level at that time. Participation of students in organizations is very important in the development of student leadership (Amirianzadeh et al., 2011). Development of student leadership must be done since primary school because the character of worker quality in the future will shape their cultural background at this age (Dina, 2013). By planning and giving the student leadership development earlier, it may gain more positive result towards students' cognitive skill, also improve the competency and commitment to join organization (Dina, 2013).

Of the various school efforts described earlier, it can be proved that the character and values of leadership, leadership participation, self-protection in leadership affect student achievement (Melton, Mallory, \& Chance, 2013). Katz-Buonincontro and Hektner (2014) stated that the formation of characters through positive and more negative emotions when students are faced with problems directly. Specifically, this article seeks to answer the question: (a) how does the primary school effort internalize the entrepreneurial competence and character through student leadership roles? (b) how does the junior high school effort internalize the entrepreneurial competence and character through the student leadership role? and (c) how does the student leadership role improve the entrepreneurial attitude in the school?

The phenomenon of unemployment rate in Indonesia has been a matter that needs concern from some parties. Based on data from the Central Bureau of Statistics (Badan Pusat Statistik, 2017) there is an open unemployment rate of 5.50 percent in 2017. Other phenomena indicated by the Central Bureau of Statistics (Badan Pusat Statistik, 2017) the highest occupational status as employees or laborers of 39.71 percent while in population with self-employed (19.13 percent), assisted non-permanent workers with 14.89 percent and lastly assisted labor status of just 3.26 percent. Therefore, it can be interpreted that Indonesians are largely uninterested in self-employment (entrepreneurial) work. Entrepreneurship is one of the efforts that can provide employment and overcome the phenomenon of high unemployment.

So, one of the most important areas to address this problem is through education. The government continues to promote entrepreneurial education activities to enhance entrepreneurial competence and entrepreneurial spirit through education integration process (Kementerian Pendidikan Nasional, 2010). Primary school education is the first step to plant entrepreneurial competence and spirit through various activities. The interest and opportunity to develop can give stimulus to students to raise awareness to play an important role in entrepreneurial activities, one of which is reviewed from the role of student leadership that was nurtured since the early age on primary education.

This study aimed to determine the entrepreneurial competence and character in elementary education through student leadership in school. The research was conducted at the level of basic education i.e. Satya Wacana Christian Elementary School and Satya Wacana Christian Junior High School Salatiga. Interesting phenomena arose in teaching and learning activities in both schools. Satya Wacana Christian Elementary students had an active tendency in their behavior and leadership character. This was shown in the activities and daily routines in the march line and supporting activities in shaping the character of entrepreneurship. Meanwhile, another interesting phenomenon found in Satya Wacana Christian Junior High School was shown in the direct involvement of students in organization activities and other school activities.

\section{Research Method}

This study is a qualitative research to determine the entrepreneurial competence and character in ele- 
mentary school of Satya Wacana Christian Primary School and Satya Wacana Christian Junior High School. It is intended to analyze the implementation of activity process of internalization of entrepreneur competence and character in elementary school. Existing activities in the learning process as well as the role of student leadership will focus researchers to review the competence and character of students.

Technique of taking data was through interview, observation and documentation of activity process of internalization of entrepreneur competence and character in elementary school. Interviews were done through structured interviews and in-depth interviews while observations were done through full observation.

The data collection in determining the source of the participants will invoke the recommendations of the researcher's subjects using Snowball sampling. The informants include students, teachers, principals, vice chief of Satya Wacana Christian Primary School, vice chief of Satya Wacana Christian Junior High School and some other school residents related to the role of student leadership.

After the data collected, researchers would use data analysis from Spradley. Spradley (2016) stated that data analysis is done by analyzing of domain, domains obtained from the field and then searched semantic relationship. That was classification of domains which would be the basic of the data analysis. Domain analysis from Spradley such as: a) making semantic relation pattern, b) making domain analysis worksheet, c) selecting the similarities on the interview and observation, d) seeking the covering, e) making the structural questions and f) identified domains list.

\section{Result and Discussion}

The basic education level consists of elementary and junior high school, especially in this research is Satya Wacana Christian Elementary School and Satya Wacana Christian High School. The researcher classifies several domains in this analysis: a) strategy of activities in playing the student leadership role, b) self-motivation of students in the role of leadership, and c) outcome implementation of leadership roles. Some of these domains will be exposed from both primary school levels to know the school's efforts in internalizing entrepreneurial character through the role of student leadership in school.

\section{Leadership Activity Strategy}

Based on the findings in the field of elementary school students participate actively in school activities in terms of their leadership role aspect. The first leadership activity is that students are able to lead themselves to arrive on time. This is evidenced that every morning before the school hour starts, they always come early. In addition, the teacher acts as an example of discipline. This form of leadership as a form of leadership leads itself to appreciate their time and be responsible as individuals who are obedient to school rules and policies.

Elementary school students have also been directed by the schools to play a role in leadership activities in the classroom. "I was once being the vice chairman of the class but this has changed... the roles were changed every one month..." (S-WF.4,5). Based on this, the students will do their duties as the head of the class, arranging for the time to line up before entering the class, before starting the lesson, and before taking a break. In addition, the class also consists of organizational structure: "some divisions are running for the management, such as spiritual division, competition division, ceremony division, the chairman, vice chairman, treasurer, and secretary." (S-EA.40). The school culture in elementary school found awareness in lining-up before entering the class before the first hour and after the break. "..one of the trust given by the teacher at first kept being monitored, they make their own rules so I do not give them rules" (S-S.5). This teacher explains that the class itself makes the rules in creating classroom order. "... Including the lining up because the 5th grade went back to self-contained but still keeping an eye on them... The culture of order and discipline emerged in themselves so that either they are waited by the teacher or not, they will always be the neat rows." (SS.5).

In supporting the competence and character of the students themselves, the school provides a program of morning devotions held before the first lesson begins. This activity aims to equip students in spiritual activities and as a form of surrendering themselves to God in the learning process activities in school. Students in this activity are given the roles to involve including: leading singing spiritual songs and leading prayers as well as telling their experiences on a particular topic. The higher the grade level is the greater the trust given. This is apparent in the morning reflection activities for classes 1-4 read a book rehearsed by the homeroom classroom while for the class 5-6 read the book self-meditation. "Grade 1 and 2, because they are still little children, they are still awaited and read by teachers" (S-KL.8). Teachers also provide reinforcement after reading a book in the form of messages, conclusions and applications to be done at school, environment and at home. 
Some activities that provide a leadership role in primary school students are the responsibility of carrying out class cleaning schedule after the learning ends. This indicates the role of the students in contributing to their respective tasks and working with other students in the timetable of class cleaning schedule. Another thing that can indicate a student leadership role arises is when the learning process in the classroom is done through the learning method used: "leadership can sometimes be through class discussion ...." (S-S.38) Stimulation to the child in this discussion process provides them with experience to play a role in leadership such as expressing their opinions, leading their friends while speaking and while doing other activities.

At the next level of basic education is the Satya Wacana Christian Junior High School Salatiga. The role of students in leadership activities is seen in several ways including: Students in this case the head of the class, can lead his friends to line up first before entering the class: "when the class supervisor is having a meeting, his students will make a line by them-selves led by the chairman, .. he knows that when the bell is ringing, they must stand and make line" (S-P.4). Students engage in morning devotional activities such as reading a book of reflections, leading their friends and teachers to pray. In addition to the morning school devotion, the school also provides weekend devotion which is scheduled every Friday. This activity was also led by students involved in the student council of junior high. They give each class a turn to lead the weekend devotions. After the school activity ended, all the people of the school sang the national song standing up and sang wholeheartedly: "So after reflection, class supervisor coaching, singing Indonesia Raya with the music guided by the school, and every day when it's time to go home, there will be no classes that will go home first. When the bell is ringing as the end of the lesson hours, everyone should sing the regular song" (PAN.9). Thus, students play a leadership role in every school activity in accordance with the schedule that has been made and organized according to the direction of the class supervisor and headmaster.

Another role of leadership is also seen in the form of student council involvement as a member of the Organization of Student Council: "in this Student Council, I am participating in the ceremony division, organize the schedule or perform as a ceremony officer" (S-DP.9). The responsibilities of other members of the student council organization are to conduct activities in accordance with the Student Council program such as valentine's day, Passover day (celebration of death and resurrection of Jesus),
Kartini's day, Independence day, Lab day, Christmas, wall magazine competition for educational day, 9th grade: "Student Council has a prom night activity to let off the seniors when they are about to graduate ... zero funds from school and they are looking for money by selling, ... selling out, they are also looking for sponsors, live music ..." (S-AN.23). Some of the activities of student council organization are pretty much designed to be hosted by members of the Student Council. Other Student Council activities are routinely carried out by keeping the student cooperative schedule at rest. Thus, the role of leadership through this organizing activity can be found in junior high school.

The role of students in leadership activities in junior high schools can also be demonstrated in the student's efforts to play a role in the performance of the ceremony. This is apparent in the preparation of ceremonial exercises accompanied by their homeroom teacher. The implementation of this activity is done by classes in rotation. The researcher also found the role performed in carrying out the duties and responsibilities of class picket. Students clean up the classroom after the last hour lesson is finished by sweeping, closing the class curtains and lifting class seats on the tables available for student study. These activities also imply that they are able to actively play a role in the responsibilities given by schools, especially their respective classes. In the learning process, especially in the students' learning subjects, they are encouraged to engage in group activities to discuss the design of their products. The results of group design were also presented in front of the class and responded by other groups. This shows the group's efforts to participate according to their respective duties to contribute to the subject.

\section{Motivation in Playing the Leadership Role}

The process of student participation in leadership activities is inseparable from the fundamental reasons they perform the role it takes. This can be demonstrated through motivation that is encouraged to be fully involved through various activities.

Primary schools provide an effort for students to participate directly in school activities. Based on the results of interviews and observations, there was some strong motivation or encouragement of students to perform a role in leadership. Some of these motivations include: student awareness in meeting the needs of classrooms or a clean school environment. In addition, students also act so because there are consequences or sanctions that must be borne if not 
carrying out its responsibilities: "for example if they do not do their responsibility of the class cleaning schedule, they will not be scolded by the teacher, but they get a fine and three days additional for their cleaning schedule". (S-CR.8). The motivation of the next elementary school students is the orientation of the results, this is obtained if the student is able to perform the assignment given by the teacher then the task will be completed and successfully work according to the teacher's direction. Another student encouragement is willing to play a role in leadership because of leadership experience; this is conveyed by a student: "hard, but it is good have experience." (SEA.38). Thus, it can be seen that the efforts of students in a role in leadership activities are influenced by several factors both from within himself and from outside himself.

The motivational impetus that is found in the junior high school students, among others: students learn to communicate in the process of discussion of tasks assigned by the teacher. This is as a means of students to determine their decisions in doing the task, especially in the subject of the workshop which should be group discussion, product design presentation and practice of their work. By practicing communication skills and problem solving, students are able to control the problems facing their group. Another encouragement is through the cooperation of students to accomplish the tasks together that have an impact on their results: "co-operation, because in the learning process, there should be a cooperation to complete the task." (S-DP.10).

In the activities of Student Council organizations, students are motivated to know the roles and responsibilities as members of the Student Council. The first student organizational activity is Valentine's Day which aims to foster mutual respect and love for all people. Some of the preparations were made by Student Council to achieve the target of the activity: "There is a fund raising, make decorations, find the necessary equipment, and on the D-day, manage all the preparations required." (S-BP.2). Some of the efforts made to support the achievement of the activities in question is the role of members Student Council venture funds. They create the creativity of opportunities to be used for fundraising. This is also done based on the experience of the older generation of members of Student Council, by imitating and innovating in fundraising that can raise their role in leadership. As a form of support, the school also provides support for basic leadership training activities for Student Council members to prepare them to organize and manage Student Council activities.

\section{Leadership Role Application Outcome}

The role of students in leadership in schools is done in various activities. They take the initiative to continue to be involved through various motivations both from inside and outside of themselves. Primary schools formed outcome of the role of students in leadership activities include: the formation of character in students. The characters in question are responsible and self-reliant in their leadership tasks, involved as class administrators, cleaning duty tasks, and making a line. The right responsibility for school activities provides for the formation of self-discipline because it takes a leader to do his job. The next character is action-oriented, which this is evidenced by the efforts of those who do not even monitored in carrying out the role of leadership.

There is an interesting phenomenon also in the learning activities that students can independently carry out their leadership tasks although they are not being accompanied and supervised homeroom. The line making is done by the whole class simultaneously as they listened to the school bell rang. This action-oriented character also appears in the students because the students perform based on consciousness not on the coercion from the teacher or the authority above it.

The next outcome is a competence in portraying leadership such as ability in problem solving and communication skills through a leadership experience such as a disrespect as a leader that requires strategies and competences in communicating to his friends. Coordinate is not easy: "it's hard especially if you have to be fierce, it's not good because you have to shout." (S-S.38). Thus, the student will attempt to communicate skillfully in acting as the leader in the class.

In addition to character formation occurring in elementary school students, this also happens to students in junior high school. Based on some leadership activities involving students to portray leadership activities in the school environment there are outcomes as follows: students are able to lead themselves through always coming on time in the morning and every other activity. This shows the character of discipline formed within students. The other roles of the students are responsible for their duties and responsibilities of becoming class administrators, the first line before the start of the class, carrying out class cleaning duties, participating in the ceremonial service, or leading other students for discussions in learning and group assignments, such as leading singing, and leading prayer. Although this does not apply to all students but all have the opportunity to lead these 
activities because they rotate by the presence of class or period.

The next outcome is that students are able to organize and manage student organizations intraschools with various activities and problems. Of the several activities Student Council students will naturally work hard with task responsibilities according to positions owned. Overall Student Council has several programs that have been designed in one period and make the organization's reference work.

Once a Student Council activity will design the event, plan the required funds, some other purposes to achieve the target activities. In their implementation they find obstacles such as limited funds that generate their creative ideas to dig up funds to achieve the target expenditure required. They are also responsible with their respective duties on the role of a small committee. This achievement is not necessarily can be done alone so that the character of cooperation among members with each other. Difficulties experienced by students sometimes require consultation through discussions between committee members, members of Student Council and teachers coaching Student Council.

Looking at the competence and character shaped outcomes that can be formed in students after playing the role of leadership, students are also able to participate in other social skills such as conflict management skills and time management, ability in problem solving, communication skills, and ability in decision making.

Activities that provide opportunities for students to play a role in leadership can be raised on the description of the results of researchers in the field. Aspects of activities are conducted by elementary and junior high school level by considering the characteristics of students, education level and some other things that distinguish the ability and skills of students. Schools can develop student leadership roles so they must be internalized and become the goal of the school education system. Internalization can be done through skill-based leadership activities and preparing curricula that are applied to pre-school, elementary and high school with class leadership experience.

Some of the things that determine students involved in the role of leadership are caused by several things: individual factors such as emotional intelligence, confidence. The second is to have as much experience as possible in both classroom positions and student organizations or peer relationships, most recently because of the supportive school environment (Mozhgan et al., 2011). In the implementation of the basic education level of encouragement which is the reason students in leadership are their curiosity in leadership activities, the acquisition of experience also becomes the basis for students to find out and practice the principles of leadership in their school environment. In addition, student-centered leadership activities can be supported by co-curricular activities (Bokhari, Razali, Yusof, Zakaria, 2015). It is also supported by data in the field that some activities that can be given as an opportunity for students to develop leadership is through the activities of reflection, ceremony, picket cleaning, student organizing activities in the school environment and various other activities.

Through the implementation of leadership activities obtained some of the characters that can occur include: self-confidence, charisma and integrity (Chai, 2015; Zekan, Peronja, \& Russo, 2012), student creativity (Sokol, Gozdek, \& Figursa, 2015), responsible and considerate (Zekan et al., 2012). Based on interviews and observations at elementary level, both primary and junior high schools form the character of responsibility, creativity, discipline, independence, action-oriented initiative and honesty.

Character that is formed from the process of leadership role of students is character owned entrepreneur. The leadership role is as an effort to internalize entrepreneurial competence and character. It has something in common in the process. The entrepreneurial character in question consists of: Independent, Creative, Brave, Action oriented, Hard Work, Honest, Discipline, Innovative, Responsibility, Cooperation, Unyielding, Commitment, Realistic, Curiosity, Communicative, Strong motivation for success (Kementerian Pendidikan Nasional, 2010). However, the Ministry of National Education of Republic of Indonesia (Kementerian Pendidikan Nasional, 2010) explained that educational units cannot directly implement all of the characters to the students. It needs to be done periodically. There are at least six main values in implementing character: independent, creative, dare to take risk, practical-oriented, leadership, and hard work. Based on existing data, found that there are characters in students have fulfilled the basic character of the entrepreneur according to basic education level.

In addition to character, leadership roles also have an impact on competences formation. One of the student's formable skills is communication since communication can give a significant support to entrepreneurship activity (Abbasi, Siddiqi, \& Azim, 2011). Student performance can be formed from the student's responsibility process in the classroom environment such as: developing practical and project-oriented classes, demonstrating the full and effective tasks, the application of time management techniques, the acceptance of suggestions and critiques to ability 
in communication, demonstrations good interpersonal skills, demonstrate honesty in social relationships, efficient and effective planning and solutions to problems encountered, and improve performance (Abbasi et al., 2011). Thus, there is a connection between the activities of students in the role of leadership in the school environment with existing outcomes.

Program activities that support the role of student leadership can effectively enhance students' skills, including: motivation to achieve goals (tasks, responsibilities), communication skills, group skills, problem-solving skills, awareness of responsibilities and beliefs, and emotional control skills (Parlar, Türkoğlu, \& Cansoy, 2017). One skill development effort can be gained from interaction results in existing communities or organizations (Barch, Harris, \& Bonsall, 2012), the organization also improves the character of student personality in the role of leadership (Amirianzadeh et al., 2011); even the role of student leadership can improve student learning (Dina, 2013). This is also supported by Zekan et al. (2012) stating that development of a leader is to provide an understanding of leadership skills and abilities and recognize effective leaders in their personal. Thus, the personalities of the students who portray leadership, their leadership skills and competencies have an impact on the achievement of their goals and their future or become effective leaders (Anastasiadou, 2014).

\section{Conclusions and Implications}

So, it can be concluded that entrepreneurial competence and character needs to be instilled in the school students themselves starting from basic education level. The results showed that the internalization of entrepreneurial competence and character had been applied in basic education through leadership activities so as to form the character and leadership skills of students in school. Entrepreneurial competence and character are also able to be obtained from the role of student leadership in school.

The role of leadership can be done both in learning activities (intra-curricular), co-curricular and other self-development activities such as engaging in student organizations. Some of the aspects discussed in this article are activities that provide a platform for students to develop their leadership role in the school, personal encouragement to play a role in leadership activities and outcomes that result from their role through leadership activities.

Students' activities include student involvement in class cleaners, members of the class organization, reflective activities, school activity officers such as ceremonies and other activities and student involvement as members of the intra-school student organization for junior high school. As for the reasons on which they develop their leadership is their curiosity in participating in leading and gaining experience from field activities. Thus, schools can obtain some outcomes such as student character and skills in: communicating, problem solving skills, emotionnal control skills, time management skills and goal achievement. Thus, the character of this skill is derived from the leadership process which is also an effort to internalize the entrepreneurial character.

This study has implications for the school's efforts to give full attention to providing opportunities for students to play a role in leadership activities and to provide support through a curriculum that supports the internalization of entrepreneurial competence and character in various aspects of school activities in an integrated manner.

\section{References}

Abbasi, M. H., Siddiqi, A., \& Azim, R. A. (2011). Role of effective communications for enhancing leadership and entrepreneurial skills in university students. International Journal of Business and Social Science, 2 (10), 242-250.

Ahmad, S. Z. (2013). The need for inclusion of entrepreneurship education in Malaysia lower and higher learning institutions. Education + Training, 55(2),191-203.

Amirianzadeh, M., Jaafari, P., Ghourchian, N., \& Jowkar, B. (2011). Role of student associations in leadership development of engineering students. Procedia-Social and Behavioral Sciences, 30, 382-385.

Anastasiadou, S. D. (2014). Students' attitudes toward effective leadership in education. ProcediaSocial and Behavioral Sciences, 143, 941-946.

Badan Pusat Statistik. (2017). Agustus 2017: Tingkat pengangguran terbuka (tpt) sebesar 5,50 persen. Jakarta: Badan Pusat Statistik.

Barch, J. C., Harris, R., \& Bonsall, D. L. (2012). Leadership education as character development: Best practices from 21 years of helping graduates live purposeful lives. Journal of College \& Character, 4(4), 1-12.

Bokhari, N., Razali, A., Yusof, F. M., \& Zakaria, N. (2015). Role of uniform bodies in inculcating leadership skills. Procedia-Social and Behavioral Sciences, 204, 343-351.

Chai, M. S. (2015). Personality and leadership qualities among student leaders. American Journal of Applied Psychology, 4(3-1), 27-32. doi: 10.11648/ j.ajap.s.201504 0301.15. 
Dina, A. T. (2013). Challenges faced by educational leadership on influencing student learning. Procedia-Social and Behavioral Sciences, 93, 290295.

Fayolle, A. (2006). International entrepreneurship education issues and newness. Massachusetts, USA: Edward Elgar Publishing Limited.

Ghina, A. (2014). Effectiveness of entrepreneurship education in higher education institutions. Procedia-Social and Behavioral Sciences, 115, 332-345.

Gutierrez, J. G., \& Baquero, J. E. G. (2017). New cross-proposal entrepreneurship and innovation in educational programs in third level (tertiary) education. Contaduría y Administración, 62, 239-261.

Heydari, H., Madani, D., \& Rostami, M. (2013). The study of the relationships between achievement motive, innovation, ambiguity tolerance, selfefficacy, self-esteem, and self-actualization, with the orientation of entrepreneurship in the Islamic Azad University of Khomein Students. Procedia-Social and Behavioral Sciences, 84, 820826.

Kadir, M. B. A., Salim, M., \& Kamarudin, H. (2012). The relationship between educational support and entrepreneurial intentions in Malaysian higher learning institution. Procedia-Social and Behavioral Sciences, 69, 2164-2173.

Katz-Buonincontro, J., \& Hektner, J. M. (2014). Using experience sampling methodology to understand how educational leadership students solve problems on the fly. Journal of Educational Administration, 52(3), 379-403.

Kementerian Pendidikan Nasional. (2010). Pengembangan pendidikan kewirausahaan. Jakarta: Badan Penelitan dan Pengembangan Pusat Kurikulum Pendidikan.

Küttim, M., Kallaste, M., Venesaar, U., \& Kiis, A. (2014). Entrepreneurship education at university level and students' intentions. Procedia-Social and Behavioral Sciences, 110, 658-668.

Melton, T. D., Mallory, B. J., Chance, L. (2013). The relationship of leadership and student achievement across societal cultures. Procedia-Social and Behavioral Sciences, 106, 3052-3061.
Mortan, R. A., Ripoll, P., Carvalho, C., \& Bernal, M. C. (2014). Effects of emotional intelligence on entrepreneurial intention and self-efficacy. Journal of Work and Organizational Psychology, 30, 97-104.

Mozhgan, A., Parivash, J., Nadergholi, G., \& Jowkar, B. (2011). Student leadership competencies development. Procedia Social and Behavioral Sciences, 15, 1616-1620.

Parlar, H., Türkoğlu, M. E., \& Cansoy, R. (2017). Leadership development in students: Teachers' opinions regarding activities that can be performed at schools. Universal Journal of Educational Research, 5(2), 217-227.

Rokhman, R., Syaifudin, A., \& Yuliati. (2014). Character education for golden generation 2045 (National character building for Indonesian golden years). Procedia - Social and Behavioral Sciences, 141, 1161-1165.

Rubens, A., Schoenfeld, G. A., Schaffer, B. S., \& Leah, J. S. (2018). Self-awareness and leadership: Developing an individual strategic. The International Journal of Management Education, 16, 1-13.

Silanoi, L. (2012). The Development of teaching pattern for promoting the building up of character education basedon sufficiency economy philosophy in Thailand. Procedia-Social and Behavioral Sciences, 69, 1812-1816.

Sokol, A., Gozdek, A., \& Figursa, I. (2015). The importance of teacher leadership in shaping the creative attitudes of students. Procedia - Social and Behavioral Sciences, 197, 1976-1982.

Spradley, J. P. (2016). The ethnographic interview. United Stated: Waveland Press, Inc.

Welsh, D. D. H. B, Tullar, W. L., \& Nemati, H. (2016). Entrepreneurship education: process, method, or both? Journal of Innovation \& Knowledge, 1, 125-132.

Zekan, S. B, Peronja, I, \& Russo, A. (2012). Linking theory with practice: Students perceptions ff leaders and leadership characteristics. ProcediaSocial and Behavioral Sciences, 41, 237-242. 